\title{
Artista contemporáneo busca público al que enfrentarse. Sobre el arte como hecho comunicativo
}

\author{
Luis D. Rivero Moreno \\ Universidad de Granada
}

RESUMEN:

Desde comienzos del siglo XX, el objetivo de la vanguardia fue la ruptura con los condicionantes que limitaban la comunicación en el hecho artístico. Las tentativas de hacer fluir la comunicación entre artista y público se han basado en diversas estrategias: de la socialización de la creación a la disolución material de la obra como elemento intermedio. Gran parte del arte contemporáneo ha tratado de convertir al público en partícipe, o bien conseguir involucrar al artista en la sociedad. Una tercera salida será la de la presencia física de artista y público en un mismo lugar y mismo tiempo.

\section{PALABRAS CLAVE:}

Arte contemporáneo; semiología; artista; público; participación en el arte.

\section{ABSTRACT:}

Since the early twentieth century, the goal of the avant-garde was the break with the constraints that limited the artistic communication. The attempts of flowing communication between artist and audience have relied on different strategies: from the socialization of creation to the material dissolution of the work as intermediate between both. Much of contemporary art is built on the attempt to turn the audience into a participant, or get involve the artist in society. A third output will be the physical presence of the artist and audience in the same place and the same time.

\section{KEY WORDS:}

Contemporary art; semiology; artist; public; participation in art. 


\section{Introducción}

El arte, en un sentido general, ha sido tradicionalmente entendido como un producto físico, un objeto (la obra); realizado por un productor (el artista), fruto de una valía manual o técnica adquirida en el tiempo o entendida como "don" natural y congénito. Esta obra sería realizada habitualmente satisfaciendo las premisas expuestas por un comitente individual o colectivo. Finalizado el proceso de realización de la obra, con mayor o menor fortuna, ésta sería finalmente acogida por un receptor (en un espacio privado o público) al ser expuesta en un contexto adecuado para este fin (museo, galería...). En la configuración clásica del medio, el arte se convierte en la conjunción de todos estos elementos y sus relaciones.

Son muchos los acercamientos que se han hecho desde una perspectiva semiológica al arte, desde los estudios pioneros de Mukarovsky $^{1}$ a obras de un inconmensurable impacto como las de Umberto Eco o Roland Barthes. La teoría semiótica se ha aplicado como herramienta de reflexión a todos los períodos y medios, desde el arte rupestre al cine. Aunque sin duda es su aplicación a los nuevos medios surgidos desde la II mitad de siglo XX la que ha abierto mayores posibilidades de análisis. $\mathrm{Su}$ influencia se hace directa en el arte actual, pues gran parte de los movimientos y artistas contemporáneos basan sus creaciones en el conocimiento exhaustivo de los pormenores de la utilización de un lenguaje representativo basado en signos y símbolos.

Todo estos autores han analizado las elementos que conforman la comunicación y la interpretación de las representaciones artísticas. Frente a la tradicional prioridad establecida por la historiografía sobre el papel del autor, la semiótica ha procurado un análisis del lenguaje y los códigos utilizados en el arte de un modo que trata de huir de lo emocional y psicológico. Por ello el rol del artista retrocede y termina por perder fuerza hasta establecerse como herramienta indispensable en el inicio del proceso pero no en su culminación. Ese final está ocupado por la figura del público. El público-receptor de la obra (entendida ampliamente en un sentido de acción o hecho artístico) se plantea como figura elemental en la fase final

MUKAROVSKÝ, Jan, Escritos de estética y semiótica del arte, Editorial Gustavo Gili, Barcelona, 1977. del proceso y sin el cual la comunicación planteada por el arte sería incompleta, y, por tanto, quedaría truncada.

Por otro lado, la obra de arte, como elemento central, eje de unión de todas las tensiones, se ha basado a lo largo de la historia en su carácter sígnico y simbólico, el de la re-presentación: la presentación mediante imágenes de un referente lejano, no presente. Las ideas o hechos representados, realistas o ficticios, adquirirían en todo caso un carácter de signo físico. De ahí que las relaciones entre artista y público, entre emisor y receptor de la obra artística, se vean aún más distanciadas, inter-mediadas principalmente por la obra.

Este artículo realiza un acercamiento al hecho artístico desde el punto de vista de la antropología visual $\mathrm{y}$, principalmente, la semiología: como acto comunicativo utilizador de signos. Se pretenden así establecer las características que han llevado al arte contemporáneo a tratar de acercar las figuras de artista y público a través de diversas tácticas. Entre ellas se establecería la desmaterialización de la obra, su consecución como mensaje tendente a la abstracción y no objeto físico, llevada a sus últimas consecuencias por los nuevos medios digitales. La concepción del arte como lenguaje que se atiene a unos códigos que deben descifrarse e interpretarse será la base sobre la que se asentarán los planteamientos semiológicos. Los propios creadores contemporáneos han realizado un progresivo énfasis en la reflexión del arte como hecho comunicativo. Derivado de ello se han multiplicado las preguntas sobre el indispensable papel del público en el proceso, en una tendencia en la que éste último ha robado parte del protagonismo a la obra y su autor. $\mathrm{El}$ arte contemporáneo ha cargado tintas en su carácter meta-artístico, de reflexión sobre sus propios mecanismos.

Sin embargo esta investigación centra su atención en aquellas otras estrategias utilizadas por ciertos artistas contemporáneos con el objetivo de agilizar el acto comunicativo, reducir su mediación de técnicas y herramientas. En todo caso se dará visibilidad a los canales y medios utilizados, denunciando la tradicional tendencia a la naturalización de éstos por parte de la institución. El artista comenzará un proceso comunicativo que nunca será puro ni cerrado y estará sujeto a multitud de condicionantes. En última instancia la síntesis del proceso quedará reducida a la necesidad de artista 
y público como elementos esenciales, iniciador y culminador del hecho artístico como acto de comunicación.

La obra se convierte así en algo vivo, que sólo ocurre una vez, en un momento establecido, y que, sin embargo, puede ser continuada en el tiempo al ser recibida por futuros espectadores-lectores en forma de documento. En todo caso el objetivo será la consecución no ya de un público pasivo, sino su incorporación física y activa en el proceso, señalando su necesidad en el mismo. La táctica final llevará a suprimir cualquier distancia espacio-temporal, para terminar por hacer concurrir en un mismo espacio y tiempo a artista y público, en un hipotético acto comunicativo abierto e interactivo, único e irrepetible. Todo ello en un paso que tiende de la representación a la presentación. Los artistas no parecen haber hecho más que salir a la búsqueda de un público al que finalmente enfrentarse.

\section{El público invisible}

Vivimos en el mundo de la imagen, rodeados de representaciones captadas, distribuidas y consumidas a través de numerosos medios. La primacía de la imagen en nuestra sociedad es evidente. En este contexto el ciudadano se convierte inevitablemente en espectador. Las imágenes, convertidas en medio de comunicación y consumo, se suceden a un ritmo frenético. La interpretación de las mismas se convierte en un hecho cada vez más codificado y simplificado. Virilio, en su teoría sobre la "máquina de visión” (1989), alerta de la tendencia a la industrialización de la producción y distribución de imágenes, así como la final automatización de la percepción ${ }^{2}$. La multiplicación de la creación y difusión de representaciones derivaría en la pérdida de autonomía del receptor de la obra, consumidor de imágenes precocinadas, en un proceso que otorga al espectador un carácter secundario, de receptor pasivo, en imágenes que parecen ya no generarse en su cerebro, tan sólo acumularse en el mismo.

Las posibilidades y alcance de la capacidad de la visión no son un tema baladí. Foucault ya señaló la vigilancia como medio fundamen-

\footnotetext{
VIRILIO, Paul, La máquina de visión, Cátedra, Madrid,
} 1989, p. 77. tal de control social por parte del poder ${ }^{3}$ La primacía de la posición del observador ha sido una constante desde los inicios de nuestra civilización. Es imposible entender la evolución artística occidental desde el Renacimiento sin atender a los avances en el control científico y técnico de la perspectiva.

La importancia concedida a la visión, al punto de vista, haría del espectador el único individuo capaz de realizar juicios estéticos válidos sobre la obra artística, subrayando además que este observador (en su grado más alto: el filósofo) debe tener una posición desinteresada y distanciada sobre el objeto artístico. Desde la filosofía clásica se ha entendido al artista como incapaz de ofrecer un juicio cognoscitivo sobre la obra debido a su implicación en primera persona en el proceso. La distancia sobre la producción artística se ha reivindicado como necesaria para la válida comprensión del arte en un sentido general y no contaminado por condicionantes afectivos.

En este contexto debemos situar la figura del público. Matizando, aún podríamos establecer diferencias entre un público potencial del hecho artístico, masa plural y social con la capacidad de acceder a ella, y el espectador, individual, sujeto que la disfruta en un lugar y un tiempo determinado. Tradicionalmente la figura del público ha vivido oculta en la penumbra del anonimato, distanciado. Los focos apuntan al escenario, mientras la platea queda en la oscuridad, ocultando al "monstruo de mil cabezas" que murmulla, latente.

El espectador, a pesar de completamente necesario, ha sido tratado con cierto menosprecio. El fin del proceso, entendido el arte como medio propagandístico, al servicio del poder, era imponer una cosmovisión al mismo. El discurso era trazado por entidades superiores que tan sólo debían ofrecer al público las claves establecidas para una correcta digestión del mensaje. Educada su mirada y "domada" su capacidad de respuesta, la cultura ofrecía el menú programado sin mayor complicación. A la imposición de las ideas a través de todo un entramado de estructuras culturales denunciado por Adorno y Horkheimer en La dialéctica de la Ilustración $n^{4}$ se continuaría en el mundo actual la llegada de

\footnotetext{
FOUCAULT, Michel, El ojo del poder. Jeremías Bentham. El Panóptico, Ed. La Piqueta, Barcelona, 1980.

4 ADORNO, Theodor W., y HORKHEIMER, Max, Dialéctica de la Ilustración, Ediciones Akal, Madrid, 2007.
} 
la llamada industria cultural, de la cosificación y mercantilización de un arte cada vez más cercano a los mecanismos de la publicidad y los medios de comunicación de masas. Ante ellos el receptor de los mensajes, se convertiría en un "hombre unidimensional", un espectador incapaz de generar respuestas propias ante ideas y opiniones preconcebidas 5 .

Ante este panorama, la brecha entre artista y público ha tendido a agrandarse aún más con el paso del tiempo. En los primeros años del siglo XX no se dudó en afirmar un proceso de "deshumanización" del arte ${ }^{6}$. El arte desde entonces, cada vez más tendente a la abstracción, impedía una comprensión básica figurativo-realista de la obra. El espectador ante ello quedaba huérfano de referentes, a merced de la conformación de infinidad de mundos de difícil inmersión. El arte pareció así complejizarse, quedando plenamente ligado a la experimentación visual y la teorización metafísica, territorios de difícil entrada para el ciudadano de a pie. La autonomía alcanzada, un objetivo prioritario desde el mismo renacimiento, pareció aislar socialmente al arte $^{7}$, individualizando su experiencia productiva y receptiva.

La autenticidad científica de los hechos se ha basado en esta postura ocularcéntrica, que prima, por encima de todo, la importancia del sentido de la vista como "testigo" de la veracidad de los acontecimientos. El arte, en todos estos siglos, había asumido esa necesidad de una perspectiva, establecida como objetiva, que imitaba las posibilidades de visión del ojo humano y que otorgaba un punto de vista único al espectador. Las obras sólo se podían observar desde un punto, creando una dirección a seguir ya impuesta de antemano.

\section{La muerte del autor}

La figura del artista ha sido sin duda sobre la que la historiografía ha vertido gran parte de sus energías a lo largo de la historia. La tradición occidental desde el Renacimiento, apoyada, corregida y aumentada en la Ilustración y

MARCUSE, Herbert, El hombre unidimensional, Ariel, Barcelona, 1987, pp. 31-48.

6 ORTEGA Y GASSET, José, La deshumanización del arte y otros ensayos de estética, Alianza Editorial, Madrid, 1981.

7 LAZY, Suzanne (ed.), Mapping the terrain: new genre public art, Bay Press, Seattle, 1995, pp. 74-77. el Romanticismo lo situaría como ser alienado, un personaje libre y autónomo ajeno en cierta forma a la realidad social. La figura del genio creador generaría una visión del artista como personaje de existencia melancólica, errante y aislada frente al común humano. Se dificultaba de este modo la posibilidad de comunicación entre un artista endiosado, perteneciente a otro rango, y un público incapaz de comprender todas las claves del mensaje debido a su menor categoría perceptiva y cognitiva del mundo.

Frente a este problema de raiz, los movimientos vanguardistas surgidos desde comienzos del siglo XX van a plantearse diferentes modos con los que tratar de reducir la brecha abierta entre artista y público. El primer problema a solventar a este respecto sería el habitual carácter críptico de las obras, con una tendecia a considerarse más vanguardistas y originales cuanto más rica, compleja e ilegible fuera la propuesta. Desde el surgimiento de los movimientos sociales y proletarios allá por el siglo XIX, la discusión sobre el compromiso político del arte se ha venido repitiendo hasta nuestros dias. Diferentes corrientes han denuniciado el papel del arte como herramienta superestructural del poder, aunque, al mismo tiempo, lo han señalado como instrumento de lucha contra la alienación, desenmascarador de las desigualdades sociales. Cualquier tipo de invasión en el espacio público por parte del arte tendrá que ser tomada desde un punto de vista político ${ }^{8}$. Arte y revolución han sido conceptos relacionados a lo largo de todo el siglo XX ${ }^{9}$. Por todo ello los intentos de unión de artistas y trabajadores se han sucedido con mayor o menor éxito desde el hito que supuso la Comuna de París de 1871 hasta la llegada de los movimientos antiglobalización a finales del segundo milenio.

Otro hecho clave para entender el mundo contemporáneo, la revolución industrial, también llevó a importantísimos cambios en la forma de hacer arte. La reproductibilidad técnica suponía la pérdida del aura de la obra, y su factible democratización a través de la copia industrial ${ }^{10}$. Con ella el artista se sometía a procesos de trabajo similares a los del obrero,

8 DUQUE, Félix, Arte público y espacio político, Ediciones Akal, Madrid, 2001, pp. 8-14.

9 RAUNIG, Gerald, "Art and revolution", en Transversal Activism in the Long Twentieth Century, 98, 2007.

10 BENJAMIN, Walter, La obra de arte en la época de su reproductibilidad técnica, Ítaca, México D.F., 2003, pp. 46-48. 
dependía de la técnica y ofrecía un arte barato donde la firma del artista tendía a perder importancia.

La idea fundamental que rondaba todo el proceso era la reintegración del artista en la sociedad de su momento, a nivel político y social. Comenzaron así a surgir corrientes artísticas defensoras de un arte comprometido, de un artista nuevamente "humano", y de un arte colectivo y colectivizado ${ }^{11}$. La integración del artista en la masa proletaria, su reubicación social en contra de la figura aislada y melancólica romántica conllevaría a una cierta anulación del artista como individuo, convertido así en un ente con el cometido de alimentar la capacidad colectiva de creación. El artista, de alguna manera, desaparece. De la expresión subjetiva pasaríamos así a un arte de orientación colectiva y social, donde de poco serviría el continente si no va de la mano de un contenido político-revolucionario $^{12}$.

Uno de los ejes fundamentales para la consecución de un arte abierto, democratizado, potencialmente desarrollable por la gran mayoría de la población y no reducido a una élite de elegidos por la musas o los genes, tiene su origen en uno de los "ismos" más influyentes de las vanguardias históricas: el dadaismo. Gracias a él, y sobre todo a la figura de Marcel Duchamp, se abrieron las vías más potentes de apertura del hecho artístico, en una "revuelta" creativa que se volvía contra las bases establecidas en la tradición histórico-artística. Consecuencia de este ataque directo, el artista se liberaba, a partir de ahora ya no necesitaría una habilidad técnica ni conocimiento de un trabajo manual específico para realizar obras de arte.

Otras vanguardias siguieron agitando este debate, defendiendo la capacidad artística que todo ser humano guarda a diferentes niveles: en el subconsciente (surrealismo); en la visualización del movimiento de la máquina o la violencia de la masa (futurismo); en la creencia en la potencia creativa del trabajo del pueblo (la vanguardia rusa). El testigo de la vanguardia histórica fue recogido en movimientos ya posteriores a la II Guerra Mundial como el art brut, defensor de la posibilidad de producción de un

11 KESTER, Grant H., The one and the many: Contemporary collaborative art in a global context, Duke University Press, 2011.

12 GRANÉS, Carlos, El puño invisible: arte, revolución y un siglo de cambios culturales, Taurus, Madrid, 2011. arte puro, completamente ajeno a los condicionantes sociales impuestos por la educación y la cultura, y constatable en las obras creadas por niños y enfermos mentales. Pero va a ser ya con la llegada de años 60 cuando movimientos sociales y arte se unan de un modo definitivo: la defensa de los derechos de las minorías, el feminismo, y la denuncia de toda desigualdad social, desde entonces, no puede entenderse sin obras artísticas que apoyen, documenten y difundan sus propósitos.

Se produce con todo esto un movimiento revolucionario abocado en muchos casos a la autodestrucción, a lo que se ha llamado el "antiarte"13, dispuesto a romper las estructuras institucionales capitalistas-patriarcales-burguesas y con ello a romper con la propia concepción impuesta del artista como individuo "especial". Esta tentativa autodestructora pretendía hacer ver a la sociedad que todo puede valer como arte, siempre y cuando haya unos ojos dispuestos a verlo como tal.

La paradoja vendrá poco después con la aceptación de este tipo de trabajos por parte de las instituciones artísticas. Teóricos como Bürger no dudarían en señalar al respecto el fracaso revolucionario de la vanguardia ${ }^{14}$. La ironía sería aplacada, y el "urinario-fuente" terminaría por ser obra de arte en exposición. Otros como Hal Foster, sin embargo considerarán que las herramientas y objetivos puestos sobre la mesa por las vanguardias históricas no se agotarán y verán continuación en los posteriores movimientos surgidos hasta nuestros días ${ }^{15}$.

La idea, y no ya el objeto había pasado a convertirse en arte, la realidad tendía a convertirse en arte, la vida en general pasaba a ser potencialmente artística. Detrás de todo esto se encontraba la constatación de la innecesaria actuación del artista en el proceso llamado artístico, ya que ni tan siquiera necesitaba de producir su obra con sus propias manos. Barthes no duda en señalar la muerte del autor ${ }^{16}$. La atención se había puesto ya necesariamente en el rol del receptor. Superada la mentira ins-

\footnotetext{
3 RICHTER, Hans, y BRITT, David, Dada, Art and Anti-Art, World of Art, Thames and Hudson, New York, 1997.

14 BÜRGER, Peter, Theory of the Avant-garde, University Press, Manchester, 1984.

15 FOSTER, Hal, El retorno de lo real, Ediciones Akal, Madrid, 2001.

16 BARTHES, Roland, "The death of the author", en Contributions in Philosophy, 83, 2001, pp. 3-8.
} 
titucionalizada de la sacralidad y elitismo, el arte ya ni tenía por qué ser caro ni difícil de entender. El público no había tenido la culpa del distanciamiento, de la incomprensión del arte, sino que las élites culturales habían tratado de mantener sus privilegios a partir de la creación de códigos indescifrables.

\section{La obra inmaterial}

La vía abierta por Duchamp supuso un inicio hacia lo que posteriormente terminaría por llamarse arte conceptual. Se iniciaba así un proceso de desmaterialización de la obra artística que se desarrolla a finales de los años 60 y comienzos de los $70^{17}$. El proceso creativo ya no tenía por qué ser un proceso físico, no daba como resultado una obra tangible y, por tanto, no necesitaba de la figura de un artista (técnico) capaz de dar forma a una materia (en términos aristótelicos). Siendo el arte un proceso mental, conceptual, la presencia física de la obra-objeto no será necesaria.

El arte se afianzaba así como lenguaje de signos en términos semióticos. Como tal, algunos autores explorarán las nuevas posibilidades ofrecidas por una comunicación estética no atada a lo físico, sino volcada en el contenido, en la asunción de un discurso ${ }^{18}$. Joseph Kosuth llevará al hecho artístico al extremo: utilizará la tautología para analizar los condicionantes del medio elegido y la arbitrariedad de los signos en la comunicación ${ }^{19}$, en una vuelta de tuerca a la crítica del engaño de la mímesis desarrollada por Magritte años antes ${ }^{20}$.

El culmen de este proceso lo obtenemos de la mano de Yoko Ono y su serie de exposiciones a partir de órdenes dadas al espectador. Con ella Ono demuestra que el artista ya no es indispensable en el proceso artístico o, al menos, reduce su intervención al mínimo, anulando su necesidad física. El artista está ausente, liberado de la necesidad de intervención manual,

17 LIPPARD, Lucy R., Six years: the dematerialization of the art object from 1966 to 1972, University of California Press, 1997.

18 PRINZ, Jessica, Art discourse/discourse in art, Rutgers University Press, New Brunswick, NJ, 1991.

19 KOSUTH, Joseph, "Art After Philosophy", en Kosuth, Joseph: Art After Philosophy and After. Collected Writings 1966-1990, 1993, pp. 13-32.

20 FOUCAULT, Michel, Esto no es una pipa: ensayo sobre Magritte, Anagrama, Barcelona, 1981. no precisa de acudir a un estudio ni taller, ni tan siquiera necesita ir al museo o la galería. Desde la distancia "ordena" acciones que sólo serán realizadas (físicamente) si el espectador de la obra se anima a cumplirlas. Aún más, el receptor, sólo con su reacción mental ante las órdenes, de algún modo completa las obras, sin tan siquiera haberlas materializado.

La desvinculación del mundo material puede ser entendida como renuncia a las leyes capitalistas donde el producto es válido a partir de no sólo su valor de uso, sino, y aún más, de su valor de cambio en término marxistas. Se rehúye así de este hecho a partir de la negación física del arte como producto, como imagen consumible, como objeto intercambiable... La práctica o experiencia artística ya no es, de este modo, una acción tan sólo realizable por un artista especializado y se convierte en la percepción estética de acciones simples, cotidianas, capaces de ser llevadas a cabo por cualquier ser humano. Por ello la necesidad de un entorno artístico (sea éste museo, academia, galería...) también se diluye, puesto que las acciones propuestas pueden ser llevadas a cabo en cualquier lugar, público o privado, sin ningún tipo de preparación ni condicionamiento especiales.

El arte conceptual reaccionaba así contra la corriente pop "espectacularizante" que asumía que toda la realidad era reducible a imagen, y que primaba la concepción de esta imagen como objeto de consumo. Sin embargo la llamada de atención sobre el espectador se nutría de modo altamente contradictorio de los mecanismos de la publicidad ${ }^{21}$.

Asumido el mundo como espectáculo en un primer momento ${ }^{22}$, el peligro mayor vendría de su conversión final en simulacro, copia sin referente $^{23}$, en una confusión creciente entre realidad y ficción que hacía ya imposible distinguir entre la imagen de una lata de sopa en un museo y la misma imagen de una lata de sopa en un supermercado. La virtualidad del simulacro, válida en sí misma supone una negación de todo signo o símbolo, un ataque directo a las bases de la semiología que amezaba con termi-

\footnotetext{
${ }_{21}$ ALBERRO, Alexander, Conceptual art and the politics of publicity, MIT Press, Cambridge, Massachusetts, 2003, pp. 1-5.

22 DEBORD, Guy, La sociedad del espectáculo, Pretextos, Valencia, 2003.

23 BAUDRILLARD, Jean, Cultura y simulacro, Editorial Kairós, Barcelona, 1993.
} 
nar con toda posibilidad de contenido tras la superficie de la imagen, y, de paso, con la dualidad fundamental de la relación de significante y significado, fusionadas. En todo caso se agudizaba la atención sobre el acto comunicativo, mercantilizado o no.

El medio en todos sus sentidos no pararía de ver multiplicar su impacto. Las tecnologías y los códigos técnicos y convenciones utilizados por ellas llevarían a una creciente influencia del medio a muchos niveles. Desde mediados del siglo XX el medio conllevaría una carga de significación inusitada que lo igualaría al propio mensaje, al contenido ${ }^{24}$.

\section{De espectador a usuario}

La carga autocrítica de la que hacen gala los artistas conceptuales o pop volvía a poner los focos sobre el proceso al completo y en última instancia sobre el público, último eslabón capaz de darle forma completa. Después de todo, arte sólo es aquello a lo que los hombres llamen $\operatorname{arte}^{25}$, por lo que el receptor final, ya entendido de una forma general, como sociedad, es el único capaz de validar la obra, hacerla artística con su aceptación, o bien anularla.

El proceso mediante el que el público pasa de elemento anónimo y secundario a primordial en el hecho artístico va a desembocar en paradoja: El público ya no será nunca más tal, al menos en su sentido de espectador, de asistente a un espectáculo, pues a partir de este momento el público será partícipe, será integrante de él, se in-corporará al mismo ${ }^{26}$. En el mundo del espectáculo ya no estará a salvo en la platea, sino bajo los focos, en el escenario. Será para siempre indistinguible del actor, indistinguible del artista, tan actuante como uno, tan creativo como el otro. Tan observante como observado. Si todo es ya filmado, si todo es imagen, el público también lo será. Y la imagen precisa ser vista, si no carece de sentido. Observando y siendo observado, terminará por ser autorreflexivo, no le quedará más remedio que contemplarse como en un espejo, y reconocerse, como uno más, en la

24 MCLUHAN, Marshall y FIORE, Quentin, "The medium is the message", en New York, 123, 1967, pp. 126-128.

25 JIMÉNEZ, José, Teoría del arte, Tecnos, Madrid, 2002, pp. 17-52.

26 PUELLES ROMERO, Luis, Mirar al que mira: teoría estética y sujeto espectador, Abada, Madrid, 2011, p. 201. pantalla. Llegamos así a la consecución de un espectador emancipado ${ }^{27}$.

El itinerario hasta llegar a este extremo no fue, sin embargo, sencillo, y pasó por múltiples fases: en un primer momento se basó en la provocación como modo fundamental de reacción. La transgresión de las normas no sólo alteraba a las conservadoras instituciones, sino que provocaba la desairada reacción social ${ }^{28}$. La llamada a la acción del público acababa de algún modo con los hasta entonces endogámicos debates histórico-artísticos, enmarcados en contextos tan cerrados como la academia. El arte conseguía así salir de su aislamiento social, provocando la reacción, el debate, el enfado, o, en algunos casos, la defensa vehemente. El arte se acercaba así a una forma de activismo social $^{29}$.

La búsqueda de la provocación directa del espectador, hasta hacerlo partícipe físicamente, se puede rastrear desde los espectáculos de dadá o el futurismo, en que es conocida la reacción violenta del público. Se eliminaba así la respuesta pre-programada y aséptica del aplauso o el silbido, hasta hacer de la obra propuesta algo tan abierto como dependiente por completo o en gran parte de la reacción de los (en un primer momento) espectadores.

La apertura de la obra de arte quizás haya sido una de las claves de la cultura contemporánea $^{30}$. Dejando la creación artística abierta (en un sentido físico y/o conceptual) la culminación de la misma tan sólo llega con el cierre de ella que haga el público (individuo o grupo). Se produce así una actualización constante que, no obstante, no debe confundirse con la aceptación de cualquier interpretación ${ }^{31}$. No todo vale, pues ésta depende de la estrategia de comunicación y, en gran parte, del público al que se dirija. De este modo se admite y defiende la necesidad de un hecho artístico activo, en constante evolución, donde ni la figura del artista ni la del receptor deban atenerse a códi-

27 RANCIĖRE, Jacques, El espectador emancipado, Ediciones Manantial, Buenos Aires, 2010.

28 JULIUS, Anthony, Transgresiones: el arte como provocación, Destino, Barcelona, 2002, p. 208.

29 FELSHIN, Nina, “¿Pero esto es arte? El espíritu del arte como activismo", en Modos de hacer: arte crítico, esfera pública y acción directa, Universidad de Salamanca, 2001, pp. 73-94.

30 ECO, Umberto, Obra abierta, Ariel, Barcelona, 1990.

31 ECO, Umberto, The role of the reader: Explorations in the semiotics of texts, Indiana University Press, 1984, p. 9. 
gos cerrados. Quizás sólo de este modo pueda entenderse al fin la comunicación artística en toda su complejidad, en su carácter polisémico, generando la necesidad de un receptor crítico.

Si el gran problema del arte había sido su lejanía de los intereses de la sociedad, producido por, para y desde asépticas torres de marfil (o cubos blancos), la procura debía ir direccionada en pos de un arte sencillo, barato y directo, en que el artista estuviera igual de implicado que el público. El arte contemporáneo debía "desmaquillarse", desembarazarse de la utilización de materiales caros y técnicas complejas, dejar de ser intocable e invitar a la participación, como si de un juego se tratara. Así la creación se liberaba de su forzada seriedad, de su carácter elitista, críptico y obstuso, dedicado sólo al entendimiento de unos pocos elegidos, para terminar por fomentar la conversación, el diálogo social ${ }^{32}$.

Surgieron en este contexto muy diversas corrientes artísticas entre las que podríamos destacar fluxus, happening y sus posteriores variaciones en todo tipo de arte de acción o performance hasta nuestros días. Con un carácter predominantemente lúdico y abierto, fluxus trató de ofrecer la práctica artística como un ámbito heterodoxo. El objetivo era abrir las posibilidades artísticas al máximo para demostrar que todo puede llegar a ser arte, hasta llegar a la afirmación extrema: "la vida es arte y el arte es vida". Llegados a este punto se rompía toda posibilidad de separación entre lo artístico y lo no artístico, se afirmaba que todo lo que nos rodea es arte y todos nosotros somos potencialmente artistas.

El happening seguía una vía similar, aunque incidiendo aún más en la necesidad de que el arte suceda en un lugar y un tiempo determinado, frente a la concepción del arte basada en la producción y muestra de objetos. Lo que se requería en todo caso era la reacción del público, incitándolo a participar de un modo activo en el hecho artístico. Por primera vez en la historia del arte, individuos no iniciados accedían a lo que hasta entonces había sido convenientemente privado y oculto: el proceso. Éste ya no es una antesala que se presupone como indispensable para la consecución de la obra, sino que se convierte en sí mismo en la

32 KESTER, Grant H., Conversation pieces: Community and communication in modern art, University of California Press, Berkeley, 2004, pp. 152-155. “obra”, y aún más, se invita a la contemplación y participación en el mismo. La acción artística sale definitivamente a la luz. El receptor ya no obtiene sólo permiso para contemplarla, sino la obligación de involucrarse en ella, in-corporarse al proceso creativo ${ }^{33}$.

Ya no se contempla un producto derivado, un resto matérico que queda tras el trabajo del artista. Desde este momento la obra sucede en un momento y un lugar determinado y de forma irrepetible. La experiencia estético-artística se hace de esta manera única, inmediata, completa, total y absolutamente inscrita en unas coordenadas espacio-temporales concretas. Tras ella ya sólo quedará la documentación de la misma. El arte deja de ser algo sacro, elitista, sobrehumano, intocable y elevado en basamentos. Por el contrario a partir de este momento es algo efímero, mundano, sencillo, disfrutable tan sólo ante la posibilidad de "estar allí" cuando se produzca. El arte ya no será nunca más la persistencia de la memoria, la documentación del pasado, para pasar a vivir en un presente continuo, con todas sus ventajas e incovenientes.

El arte de este modo reniega en primer momento de su profundidad teórica para cargar tintas en sus posibilidades sensoriales directas. Frente a un conocimiento abstracto y filosófico primará el desarrollo de una experimentación dispuesta a reactivar nuestros sentidos, habitualmente denostados en la historia de las ideas estéticas. El arte parece así apoyarse en la fenomenología de la percepción ${ }^{34}$, en la necesidad física de ser/estar en el mundo para poder conocerlo. No somos espectadores obligados a "ver, pero no tocar", sino "experimentadores", debiendo vivir la obra con todos los sentidos. Se acaba de este modo con la primacía tradicional de lo visual, sentido prioritario de la captación estética.

\section{El artista está presente. El público también}

[...] Basically the only thing that's necesary is that you create the space and time field. You announce the performance for a certain place and time. Then the public will enter. Everything

\footnotetext{
3 POPPER, Frank, Arte, acción y participación, Ediciones Akal, Madrid, 1989, p. 175-200.

34 MERLEAU-PONTY, Maurice, Fenomenología de la per-
} cepción, Península, Barcelona, 1975. 
else has to be energy dialogue with no object. That is the main thing: no object. ${ }^{35}$

La contestación a la virtualización señalada por Debord y Virilio vendrá de otra tendencia clave del arte contemporáneo: la de la reivindicación de la fisicidad del arte, la vuelta a la substancia, a la materia ${ }^{36}$. En palabras de Hal Foster un "retorno a lo real" ${ }^{37}$. Una orientación general del arte contemporáneo ha sido tratar de hacer converger sus elementos principales: artista, obra y público, en un intento de intensificar sus posibilidades de comunicación. A este respecto podríamos apreciar una vuelta de tuerca al denominado poder del centro ${ }^{38}$. Sin embargo ese centro estaría ahora marcado por el eje central del proceso artístico, el punto espacio-temporal que señala el momento de encuentro de los elementos de la comunicación artística. Ya no será el centro compositivo de la obra tradicional estudiado por Arnheim, sino el ejercicio central del acto comunicativo en que emisor, receptor y obra coinciden por fin en un mismo contexto y lugar.

Derivado de esta inusitada carga sobre un espacio y tiempo concreto se ha producido un paradójico estado de precarización de los protagonistas. Las fronteras se han borrado entre ellos, por lo que sus funciones se han hecho cada vez en más confusas y difusas. El hecho artístico parece tender a la desintegración de su estructura y la convergencia de sus componentes. Los mismos componentes parecen intercambiar posiciones, superponerse en algunos casos, cuando no colisionar.

La vuelta a la substancias supone no sólo reivindicar la fisicidad de la obra, sino, aún más, la fisicidad del artista y público. De esta manera ambos se hacen presentes, señalando y explorando sus límites corporales, mostrando su cuerpo de un modo tangible. Ya no habrá dos experiencias estéticas separadas en el espacio y el tiempo: por un lado la del artista creando la obra; después la del observador contemplándo-

35 BIESENBACH, Klaus (ed.), Marina Abramovic: the artist is present, Museum of Modern Art, New York; Thames \&t Hudson, London, 2010, p. 35.

36 LLAURADÓ, Jaime R., Genealogías del arte contemporáneo, Ediciones Akal, Madrid, 2011.

37 FOSTER, Hal, El retorno de lo real, Ediciones Akal, Madrid, 2001.

38 ARNHEIM, Rudolf, El poder del centro: estudio sobre la composición en las artes visuales, Ediciones Akal, Madrid, 2001. la. El distanciamiento ya no será posible: a la cita, en un lugar y momento dados, deberán acudir tanto artista como público, sin separaciones físicas ni jerarquías impuestas. Paradójicamente esta presencia de ambos no repercutirá en una posible pérdida de la preeminencia de la imagen (que seguirá presente a través de diferentes juegos especulares y de des-aparición en el doble) o de la importancia de la documentación en fotografía y vídeo ${ }^{39}$. El arte necesita testigos, en tiempo real o diferido ${ }^{40}$.

La tentativa de aproximación de artista y espectador tiene hitos señalados. En cualquiera de los casos el público va a seguir guardando su carácter anónimo. Mientras el artista conservará su nombre y un posicionamiento relevante, aunque sea autocrítico o paradójico. Así Piero Manzoni convertirá al público en "su" obra en Base Mágica (1961), constatando con ironía la tradicional capacidad especial del artista de convertir en obra de arte todo lo que toque (o firme). El público se hace tan necesario que se pone a disposición del artista, se convierte en "escultura viviente" y se observa ufano a sí mismo.

Pocos años después Vito Acconci no dudó en perseguir explícitamente a ciudadanos en Following piece (1969). Ante la necesidad de hacer un arte directo y la (desesperada) necesidad de involucrar al ciudadano en los proyectos, el artista terminó por invadir el espacio público $^{41}$. Este movimiento suponía la reivindicación última de la fricción de creación artística y realidad social. El artista es capaz de salir así del contexto normativo, de las convenciones del espacio artístico y asalta la calle en busca del público, de una relación física con el mismo nunca consumada.

Marina Abramovic, tras haber ensayado diferentes modos de presencia ante el público, llevará al máximo todo lo señalado en su obra magna: The artist is present, que tuvo lugar en el MoMA de Nueva York en 2010. En ella pasó largas horas sentada frente a los espectadores de la misma, que uno a uno, se enfrentaban cara a cara a la artista.

\footnotetext{
39 WAGNER, Anne M., "Performance, video, and the rhetoric of presence", en October, 91, 2000, pp. 59-80.

40 JONES, Amelia, "Presence" in absentia: Experiencing performance as documentation", en Art Journal, 56(4), 1997, pp. 11-18.

${ }^{41}$ ACCONCI, Vito, "Public space in a private time", en Critical Inquiry, 16 (4), Chicago, 1990, pp. 900-918.
} 
La acción podría tomarse como continuación y superación de todo lo visto con anterioridad, sin embargo deja lugar a toda una serie de interesantes interrogantes que invitan a reflexionar sobre la aparición del artista frente al público: el primero de ellos, frente a lo planteado por Acconci, se refiere a la necesidad de un entorno reglado, de una institución artística en un proceso contradictorio de redefinición ${ }^{42}$. El museo permite el desarrollo de la acción atendiendo a reglas marcadas previamente por Abramovic. La artista se presenta, se acerca, se deja ver, pero, eso sí, en un espacio cultural, artístico, donde sólo acudirá gente que suponemos es conocedora o tiene un interés por el arte contemporáneo y que está dispuesta a hacer una cola y pagar convenientemente su entrada.

Otro hecho inquietante se deriva de la propia figura del artista, supuestamente anónimo atendiendo en un primer momento al título de la obra. No hay firma y sin embargo la obra es publicitada y será filmada para su posterior distribución comercial aprovechando el tirón mediático de Abramovic. La artista asume toda esa tradición cultural y artística sobre sus espaldas, haciéndose en parte responsable y enmendando la tradicional ausencia de los artistas "vivos" del museo. Tras todo ello parece estar la asunción del museo como "el espacio de los artistas". Convertir al espacio museístico en lo que nunca fue, una "casa" para los artistas, y no la embalsamación y anulación de su obra.

El tratamiento igualitario de artista y público deja lugar a dudas. De forma cuasi-religiosa la artista se aparece como "chamán" capaz de absorber energía de los demás y reflectarla sobre ellos ${ }^{43}$. El público consigue una experiencia cercana a la meditación, a la concentración en el "aquí y ahora" Aunque quizás toda experiencia estética consiga en parte este efecto de enfatizar la estancia en el presente ${ }^{44}$.

El artista se presenta ante el público, con cierto carácter teatral, aunque a su mismo nivel, sin escenarios, sin basamentos que la eleven. Se ofrece más que nunca como espejo en el que el espectador se refleja. Debemos suponer que en ese momento y ese lugar, las dos personas

42 SEROTA, Nicholas, Experience or interpretation: the dilemma of museums of modern art, Thames and Hudson, London, 2000.

43 PUELLES ROMERO, Luis, Mirar al que mira: teoría estética y sujeto espectador, Abada, Madrid, 2011, p. 273.

44 SEEL, Martin, Estética del aparecer, Katz, Madrid, 2010, pp. 57-58. enfrentadas (artista-público) al fin se ven las caras, cumpliendo con el deseo del artista de asistir a la reacción ante la obra, de entender al receptor de su mensaje, así como del espectador de sentir la cercanía de aquel que decidió iniciar la comunicación.

El artista proyecta su cuerpo en el público, reconoce lo indispensable del mismo. La acción se convierte en autorretrato, en un autorretrato recíproco si se quiere. El sujeto espectador avanza, participa, entra en la obra. Mientras, el resto del público asiste a la acción. El bucle de reflejos se multiplica: el público tiene la oportunidad de introducirse en la obra y mirarse desde fuera. La identidad subjetiva del público se glorifica y cuestiona al mismo tiempo: el espectador-partícipe de la obra vive un momento "particular", subjetivo y personal, forma parte de la obra. La pregunta nos asalta: "¿acaso mirar no fue siempre formar parte de la obra?" 45 .

El carácter representantivo del cuerpo es puesto en cuestión: es imposible distinguir si el artista "es" así, "parece" así, o simplemente "aparece" así. El cuerpo actúa y proyecta imágenes de modo inevitable. Se confunde lo público y lo privado, ficticio y real. Como avisa Martin Seel en la percepción estética nada es "sólo lo que se nos aparece aqui y ahora"46.

La presencia literal del artista, su completa involucración en la obra trata de volcar el esfuerzo en su fácil comprensión para todos los públicos. Reduce la experiencia a vivencias de tipo mágico, religioso, en una vuelta a los orígenes del hombre. Representa lo que es de un modo tautológico. Procura una vuelta a la "humanización” del arte: la escala es humana, la comunicación es humana. Sintetiza la trayectoria de todo ser humano al estar aquí y ahora, estar presente.

Después de todo, el ser humano sólo consigue afirmar su identidad con la ayuda de los demás. Se identifica en el otro, se edifica sobre la imagen en los demás. Los artistas no son ajenos a este hecho. Mostrarse es afirmarse, pero sólo porque somos vistos. Somos los reflejos de los que nos miran. Toda narración termina por ser, en última instancia, algo de autobiografía. Todo retrato termina por ser autorretrato.

\footnotetext{
45 DIEGO OTERO, Estrella de, No soy yo: autobiografía, performance y los nuevos espectadores, Siruela, D.L., Madrid, 2011, p. 11.

46 SEEL, Martin, Estética del aparecer, Katz, Madrid, 2010,
} p. 67. 
Nos proyectamos en los demás para tratar de ser "yo". La comunicación es irremediable. En conclusión "[...] el sujeto no es autónomo, la mirada siempre es devuelta y la escucha siempre tiene una doble dirección" $"$.

\section{Conclusiones}

Después de todo, de las idas y venidas de las muy diversas y variadas corrientes artísticas que han atravesado el siglo XX y XXI, es posible afirmar que el arte contemporáneo ha conseguido alcanzar el objetivo de re-activar el papel del público en el hecho artístico. El público acude a los lugares donde sucede el arte o bien el arte asalta el espacio real. Nunca más la experiencia artística se verá reducida a la visión, del público-espectador se requiere un posicionamiento activo.

La obra, desmaterializada o no, sigue los mecanismos de la obra abierta, se reconoce en un proceso de cambio y reinterpretación permanente. Los artistas y las obras dejan de obviar o imponer un punto de vista al público, para jugar con su capacidad de percepción, con sus limitaciones y posibilidades, de modo crítico y autorreflexivo. Todos los elementos del acto comunicativo artístico señalan sin complejos la importancia capital del público, se refieren en última instancia a él y tratan de provocar su asistencia y reacción.

Para ello se han abierto dos vías claras: la de los nuevos medios digitales, que hacen del espectador usuario de mecanismos (internet, redes sociales...) necesariamente proactivos; o bien, la vuelta a una experiencia física, en que los sentidos actúan ante las sensaciones producidas por un espacio y un tiempo único y envolvente.

La culminación efectiva, cantidad y calidad del proceso comunicativo iniciado por el arte depende pues del público-espectador-usuario del mismo, de su conocimiento y experiencias previas y de su educación en los códigos sígnicos y simbólicos utilizados. La mayor o menor universalidad o contigencia de éstos aumentará o disminuirá la dificultad de esa comunicación. En todo caso, y más allá de las circunstancias personales de emisor y receptor, lo que parece un hecho es que el arte, entendido como lenguaje, continúa su curso. La narración es inevitable. Los mensajes, en forma de presentación o representación, abstractos o figurativos, tautológicos o metafóricos, son puestos en circulación a la búsqueda de un potencial público siempre latente. 